\title{
Is it possible to optimize the protein production yield by the generation of homomultimeric fusion enzymes?
}

\author{
Iryna Barshakh and Skander Elleuche*
}

\begin{abstract}
Background: The supply of industrially relevant biocatalysts demands an easy and efficient protein production in high yield. In a conventional approach, a recombinant protein is produced in a heterologous host enabling the manipulation of multiple parameters including expression plasmids, growth conditions and regulation of protein biosynthesis. In this study, the generation of homomultimeric fusion genes is tested as an additional parameter to increase the production yield of a heat-stable cellulase.
\end{abstract}

Findings: The LE (Lgul/Eco81I)-cloning strategy was used to generate a set of plasmids containing a single copy or two to four repetitions of the endoglucanase-encoding gene cel5A from the thermophilic anaerobe Fervidobacterium gondwanense. Serial up-scaling of shaking flask volumes from 50 to $500 \mathrm{~mL}$ were used to determine the production yield of active cellulolytic enzyme Cel5A in recombinant form in Escherichia coli. Monitoring the cellular wet weight and total protein proved that the bacterial growth rate is not depending on the production of fusion enzymes, however activity assays in combination with Western blotting analyses indicated instability effects of large homomultimeric fusion enzymes.

Conclusion: The production yield of fusion cellulases is constant with increasing molecular weights, but improved activities were not observed for recombinant Cel5A homomultimers. This strategy may serve as a starting point for further studies to generate more stable fusion proteins with improved catalytic activities and higher protein yield in the future.

Keywords: Gene fusion, Endoglucanase, LE-cloning, Protein yield, Thermozymes, Stability

\section{Findings}

The ability to express a heterologous gene and the production of its encoded protein in high yield is a prerequisite to be used in basic research and industrial processes (Rosano and Ceccarelli 2014; Tripathi et al. 2009). Extensive research has been undertaken to develop novel tools including expression plasmids, engineered strains and cultivation strategies, for the well-adapted production of individual proteins (Chen et al. 2016; Liebl et al. 2014; Makino et al. 2011; Sivashanmugam et al. 2009). Nowadays, Escherichia coli is probably the predominant and most popular model in terms of optimized production

\footnotetext{
*Correspondence: skander.elleuche@tuhh.de

Institute for Technical Microbiology, Hamburg University of Technology (TUHH), Kasernenstr. 12, 21073 Hamburg, Germany
}

of recombinant proteins in academia, while filamentous fungi, yeasts and further bacteria, such as Bacillus spp. and Streptomyces spp. are dominating industrial production approaches. E. coli is easy to manipulate and to cultivate and allows the production of proteins for purification and characterization from foreign sources, including eukaryotes and prokaryotes from extreme environments (Elleuche et al. 2015; Sivashanmugam et al. 2009; Tripathi et al. 2009). Several strategies were pursued to increase the yield of a recombinant protein, including promoter regulation and induction of transcription, utilization of multi-copy plasmids, dual expression of two genes in a single vector and optimization of incubation conditions to name a few (Horn et al. 1996; Rosano and Ceccarelli 2014; Ma et al. 2015).

\section{至 Springer}

(c) 2016 Barshakh and Elleuche. This article is distributed under the terms of the Creative Commons Attribution 4.0 International License (http://creativecommons.org/licenses/by/4.0/), which permits unrestricted use, distribution, and reproduction in any medium, provided you give appropriate credit to the original author(s) and the source, provide a link to the Creative Commons license, and indicate if changes were made. 
In this study, the effect of multiple identical copies of a certain gene is investigated by generating artificial homomultimeric fusion enzymes. In contrast to polycistronic operons, whose transcription and translation would result in separated proteins, fusion genes are preceded by a promoter region and a singular RBS and flanked by Start- and Stop-signals to provide a reliable context for translation of the complete ORF in a single step (Tan 2001; Rizk et al. 2012). Fusion proteins unite several advantages including the supply of multifunctional enzyme chimeras (by fusing different genes) in a single production step, instead of generating several enzyme-encoding plasmids and engineering individual strains to produce versatile proteins (Elleuche 2015; Rizk et al. 2015). As a proof-of-principle, the endoglucanaseencoding gene cel5A from the anaerobe thermophile Fervidobacterium gondwanense was chosen, because thermozymes are heat-stable, robust and enable easy handling under laboratory conditions (Elleuche et al. 2015). Moreover, this enzyme already displayed optimal characteristics and properties to be easily studied and tolerated fusions at the N- and C-terminal ends (Marquardt et al. 2014; Neddersen and Elleuche 2015; Rizk et al. 2015, 2016).

\section{Generation of homomultimeric fusion endoglucanases}

The LE-cloning system has been developed to ligate two or more genes into a vector system, thereby enabling the reliable and easy production and purification of multifunctional biomass degrading fusion enzymes (Marquardt et al. 2014; Neddersen and Elleuche 2015). The prototype vector $\mathrm{PQE}-30-\mathrm{LE}$ is based on the medium-copy plasmid pQE-30 (Qiagen, Hilden, Germany; utilization of ColE1 origin of replication results in 15-20 copies of plasmids in a single cell) that contains a T5-promoter and a sequence encoding the $\mathrm{N}$-terminal $\mathrm{HIS}_{6}$-tag. Moreover, this vector is adapted to be optimally used in combination with expression strain E. coli M15[pREP4]. In addition, the MCS was replaced in $\mathrm{PQE}-30-\mathrm{LE}$ by a merged recognition site for restriction endonucleases $L g u \mathrm{I}$ and Eco81I to allow step-wise ligation of DNA-fragments into a continuously growing plasmid (Marquardt et al. 2014).

Plasmids pQE-30-LE::1cel5A and pQE-30-LE::2cel5A containing a single copy of gene cel5A or two identical copies were obtained from proof-of-principle experiments in a previous study (Marquardt et al. 2014). ORFs $1 c e l 5 A$ and $2 c e l 5 A$ were excised with $L g u \mathrm{I}$ and Eco81I restriction enzymes and ligated into Eco81Ilinearized vector $\mathrm{pQE}-30-\mathrm{LE}: 2$ cel5A to give plasmids pQE-30-LE::3cel5A and PQE-30-LE::4cel5A, respectively (Additional file 1; Fig. 1a). All plasmids were tested by restriction analyses using endonucleases $L g u \mathrm{I}$ and $E c o 81 \mathrm{I}$ (Fig. 1b). Furthermore, catalytic functionality was investigated by expressing the singular gene and fusion genes in E. coli M15[pREP4] used as a host. LB-medium plates supplemented with $50 \mu \mathrm{g} / \mathrm{ml}$ kanamycin, $100 \mu \mathrm{g} / \mathrm{ml}$ ampicillin and 0.1 mM IPTG were overlaid with AZCLHE-cellulose containing agarose to detect enzymatic activity (Fig. 1c).

\section{Up-scaling the protein production in 50, 100, 250 and $500 \mathrm{~mL}$ shaking flasks}

Expression of cel5A from plasmid pQE-30-LE::1cel5A was already achieved in our previous studies and could be successfully used for further investigations including SDS-PAGE, Western blotting analyses and activity assays (Marquardt et al. 2014; Neddersen and Elleuche 2015).
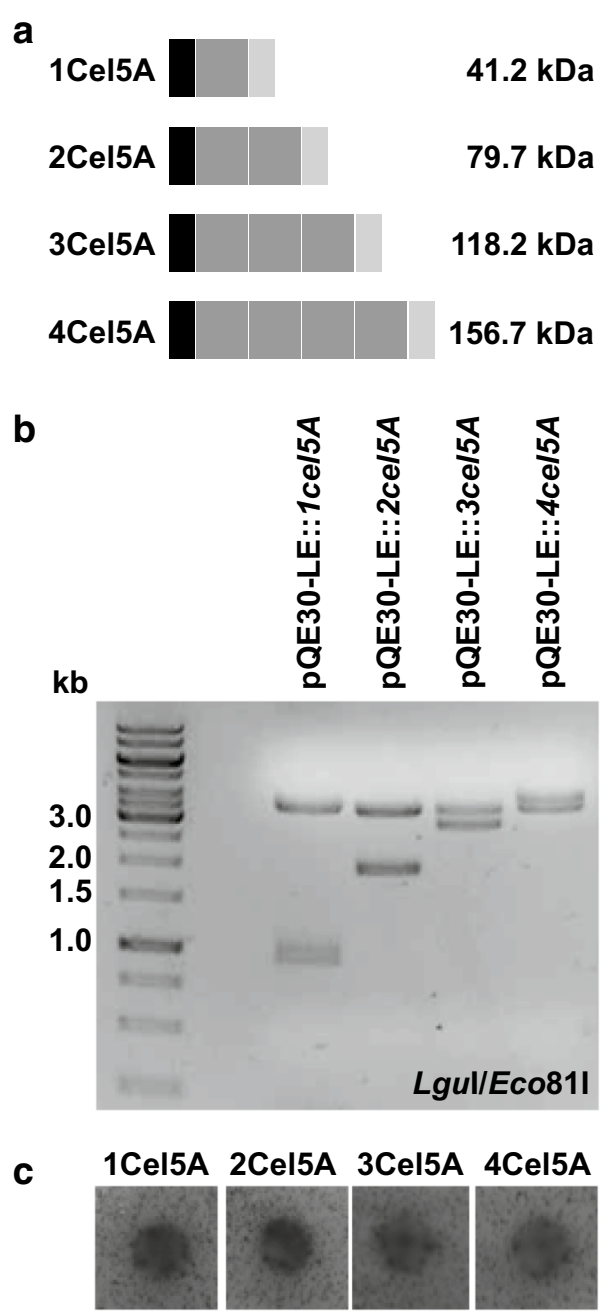

Fig. 1 Schematic diagram illustrating fusion enzymes, cloning strategy, and enzymatic activity. a Schemes displaying homomultimeric fusion constructs. Black boxes indicate HIS-tags, dark grey boxes highlight Cel5A and STREP-tags are given in light grey. Molecular weights are indicated aside. $\mathbf{b}$ Restriction analyses of cel5A-encoding plasmids using Lgul and Eco81I. c Qualitative plate activity assays with AZCL-HE cellulose used as substrate 
In the presented study, 50, 100, 250 and $500 \mathrm{~mL}$ shaking flasks were used for scale-up experiments. To exclusively focus on the repetition of the endoglucanase-encoding gene, all expression tests were done under identical standard conditions in LB-medium [1\% (w/v) tryptone, $0.5 \%$ $(\mathrm{w} / \mathrm{v})$ yeast extract, $1 \%(\mathrm{w} / \mathrm{v}) \mathrm{NaCl}$, adjusted to $\mathrm{pH} 7.2]$. A defined volume of a preincubation culture $(1 / 1000$ of target culture) was used to inoculate flasks that were further incubated under constant shaking $(160 \mathrm{rpm})$ at $37^{\circ} \mathrm{C}$ until an optical density $\mathrm{OD}_{600}=0.6-0.7$ was reached. Gene expression was induced with $0.5 \mathrm{mM}$ IPTG and cells were harvested after $4 \mathrm{~h}$ of incubation. All experiments were done in duplicate to sextuplicate. Monitoring the cellular wet weight revealed that a similar amount of cells (up to $0.8 \mathrm{~g}$ per $500 \mathrm{~mL}$ ) expressing various endoglucanase constructs were produced at each individual incubation volume (Fig. 2a). Subsequently, cells were disrupted by sonication and concentrations of soluble proteins in the crude extracts were determined using the Bradford protein assay (Bradford 1976). In good agreements with cellular wet weights, total protein concentrations in the supernatant were similar in heterologous hosts producing different sized fusion constructs (Fig. 2b).

\section{Production of homomultimeric fusion enzymes leads to reduced activities}

Total enzymatic activity from crude protein extracts was determined (Fig. 2c). Catalytic activities with $\beta$-glucan used as substrate were measured with the DNS-assay as described previously (Bailey 1988; Neddersen and Elleuche 2015). The activity of fusion enzymes is reduced when compared to the singular enzyme. There might be several reasons for the lowered catalytic performance including disadvantageous and improper folding in large fusion enzymes. In addition, the enlarged fusion proteins might be less soluble leading to the formation of inclusion bodies.

To investigate these effects in more detail, further experiments were undertaken. SDS-PAGE analyses of sedimented pellet fractions in comparison with crude proteins in the supernatant revealed that all constructs were predominantly present in soluble form (Additional file 3). Total cellular proteins (insoluble and soluble) produced in E. coli M15[pREP4] were visualized on SDS-PAGEs and Western blots using either His-Tag ${ }^{\circledR}$ Monoclonal Antibody or Strep-Tag ${ }^{\circledR}$ II Monoclonal Antibody in combination with a Goat Anti-mouse FgG AP conjugate (KGaA, Darmstadt, Germany) (Fig. 3). The obtained signals are in good agreement with calculated molecular masses: Cel5A-41.2 kDa, 2Cel5A-79.7 kDa, 3 Cel5A-118.2 kDa and 4Cel5A-156.7 kDa, but additional signals indicate that fusion enzymes were partly degraded. Interestingly, major degradation products displayed a comparable molecular weight (approx. $42 \mathrm{kDa}$ )
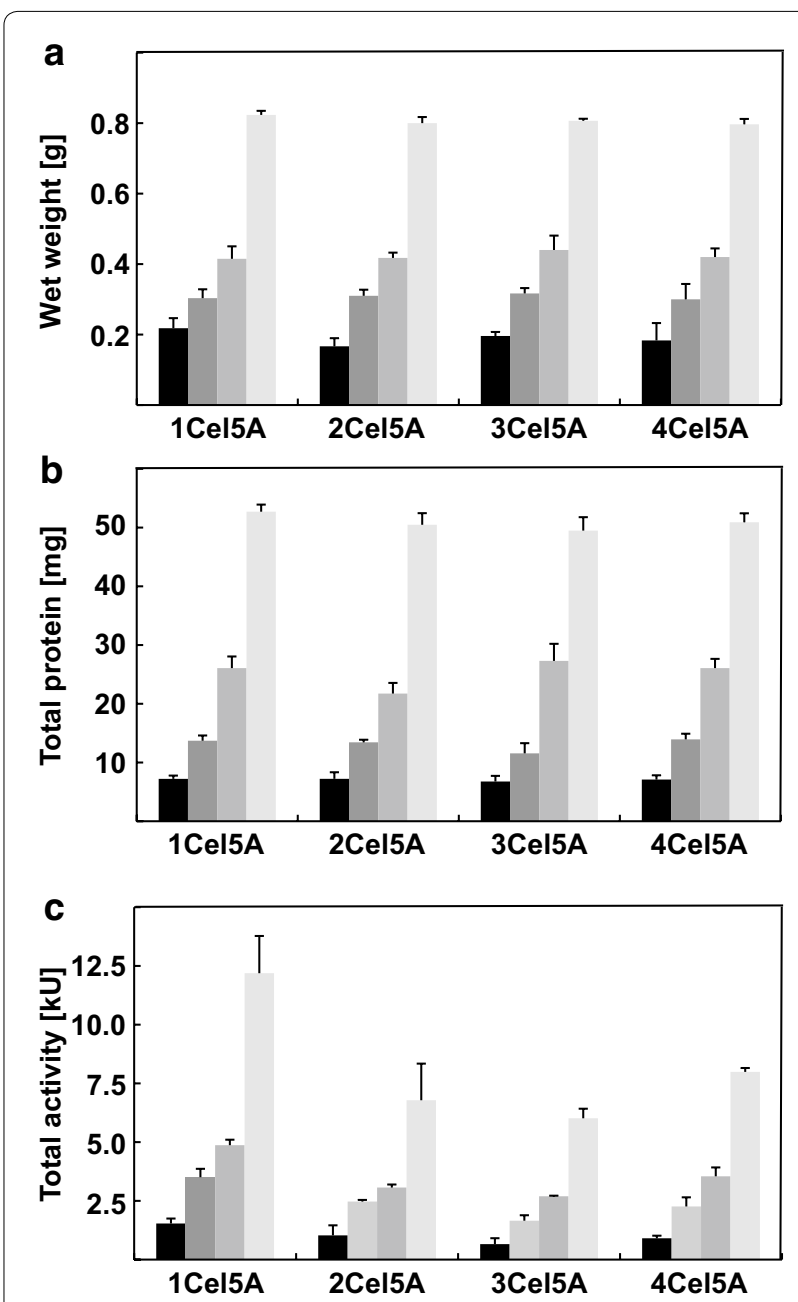

Fig. 2 Wet weights, total protein amounts and total activities of homomultimeric fusion enzymes. a Heterologous E. coli strains were grown in different incubation volumes and produced cell masses were determined. b Cells were disrupted by sonication, and insoluble proteins were sedimented. Concentration of separated soluble proteins was measured. c Total protein activities of soluble crude protein extracts were determined with the DNS-assay. Incubation volumes are indicated by the following colour code: $50 \mathrm{~mL}$ black, $100 \mathrm{~mL}$ dark grey, $250 \mathrm{~mL}$ middle grey, $500 \mathrm{~mL}$ light grey. Error bars indicate standard deviations of two to six independent measurements. Raw data from all measurements are given in Additional file 2

like the singular protein Cel5A. It is important to note that only terminal degradation products that contain an affinity tag were detectable in these Western blotting analyses, while internal parts of the proteins were not visualized. Nevertheless, breakage of the fusion enzymes at the linked regions might not come along with reduced activities, because degraded singular Cel5A moieties could restore activity. Therefore, the reduced catalytic activities in homomultimeric fusion enzymes are probably derived from folding issues, which would be in good agreement 


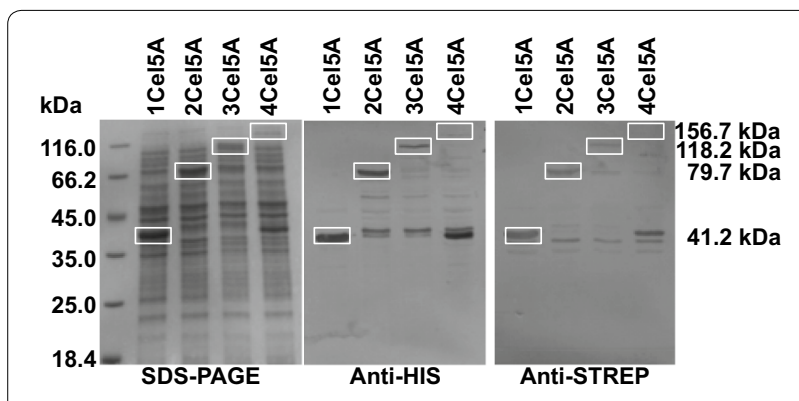

Fig. 3 SDS-PAGE and Western blotting analyses of homomultimeric fusion enzymes. Crude protein extracts from E. coli M15[pREP4] LB-medium expressing cel5A or fusion genes were separated on SDSPAGE and visualized by Coomassie Brilliant Blue staining. Degradation products of homomultimeric fusion enzymes were detected using Western blotting analyses with specific antibodies for terminal affinity tags. Full length proteins are boxed in white. Cells were grown in $500 \mathrm{~mL}$ and harvested $4 \mathrm{~h}$ after induction with $0.5 \mathrm{mM}$ IPTG

with previous observations in other studies (Hong et al. 2006, 2007; Neddersen and Elleuche 2015).

\section{Future directions}

A major disadvantage of fusion enzymes always is the molecular weight of the final constructs that are often too large to be stably kept in the heterologous host and quickly become degraded. Although, Cel5A is a robust and globular protein, fusion leads to protein instability and reduced functional product. However, this strategy might be useful to produce increased amounts of small proteins. It has been shown before that a trimeric fusion of a cellulose-binding module (pQE-30-LE::3cbm) was produced in stable form with the $\mathrm{pQE}-30-\mathrm{LE}$ system, but no functionality tests were done with this model protein so far (Marquardt et al. 2014). Finally, it is an important observation that the production of homomultimeric fusion enzymes did not lead to a decreased growth rate of $E$. coli in these experiments and further improvement including monitoring of transcription and translation levels may help to produce stable (and small) homomultimeric fusion proteins in high yield in the future.

\section{Additional files}

Additional file 1. Plasmids used in this study.

Additional file 2. Raw data of cellular wet weights, protein production yields and activities.

Additional file 3. Investigation of soluble and insoluble proteins.

\section{Abbreviations}

AZCL-HE: azurine cross-linked hydroxyethyl; DNS: 3,5-dinitrosalicylic; IPTG isopropyl- $\beta$-D-1-thiogalactopyranoside; LB: Luria Bertani; MCS: multiple cloning site; ORF: open reading frame; RBS: ribosome binding site; SDS-PAGE: sodium dodecyl sulfate polyacrylamide gel electrophoresis.

\section{Authors' contributions}

IB performed research. SE conceived and supervised the study and wrote the manuscript. Both authors read and approved the final manuscript.

\section{Acknowledgements}

SE thanks Prof. Garabed Antranikian for his generous support and the access to laboratory facilities. The authors thank Tabea Marquardt for the construction of plasmids pQE-30-LE::1 cel5A and pQE-30-LE::2ce/5A. This publication was supported by the German Research Foundation (DFG) and the Hamburg University of Technology (TUHH) in the funding programme "Open Access Publishing".

\section{Competing interests}

The authors declare that they have no competing interests.

Received: 23 July 2015 Accepted: 3 March 2016

Published online: 11 March 2016

\section{References}

Bailey MJ (1988) A note on the use of dinitrosalicylic acid for determining the products of enzymatic reactions. Appl Microbiol Biotechnol 29:494-496

Bradford MM (1976) A rapid and sensitive method for the quantitation of microgram quantities of protein utilizing the principle of protein-dye binding. Anal Biochem 72:248-254

Chen A, Sun Y, Zhang W, Peng F, Zhan C, Liu M, Yang Y, Bai Z (2016) Downsizing a pullulanase to a small molecule with improved soluble expression and secretion efficiency in Escherichia coli. Microb Cell Fact 15(1):9. doi:10.1186/s12934-015-0403-5

Elleuche S (2015) Bringing functions together with fusion enzymes-from nature's inventions to biotechnological applications. Appl Microbiol Biotechnol 99(4):1545-1556. doi:10.1007/s00253-014-6315-1

Elleuche S, Schäfers C, Blank S, Schröder C, Antranikian G (2015) Exploration of extremophiles for high temperature biotechnological processes. Curr Opin Microbiol 25:113-119. doi:10.1016/j.mib.2015.05.011

Hong SY, Lee JS, Cho KM, Math RK, Kim YH, Hong SJ, Cho YU, Kim H, Yun HD (2006) Assembling a novel bifunctional cellulase-xylanase from Thermotoga maritima by end-to-end fusion. Biotechnol Lett 28(22):1857-1862. doi:10.1007/s10529-006-9166-8

Hong SY, Lee JS, Cho KM, Math RK, Kim YH, Hong SJ, Cho YU, Cho SJ, Kim H, Yun HD (2007) Construction of the bifunctional enzyme cellulase-betaglucosidase from the hyperthermophilic bacterium Thermotoga maritima. Biotechnol Lett 29(6):931-936. doi:10.1007/s10529-007-9334-5

Horn U, Strittmatter W, Krebber A, Knupfer U, Kujau M, Wenderoth R, Muller K, Matzku S, Pluckthun A, Riesenberg D (1996) High volumetric yields of functional dimeric miniantibodies in Escherichia coli, using an optimized expression vector and high-cell-density fermentation under non-limited growth conditions. Appl Microbiol Biotechnol 46(5-6):524-532

Liebl W, Angelov A, Juergensen J, Chow J, Loeschcke A, Drepper T, Classen T, Pietruszka J, Ehrenreich A, Streit WR, Jaeger KE (2014) Alternative hosts for functional (meta)genome analysis. Appl Microbiol Biotechnol 98(19):8099-8109. doi:10.1007/s00253-014-5961-7

Ma W, Cao W, Zhang H, Chen K, Li Y, Ouyang P (2015) Enhanced cadaverine production from L-lysine using recombinant Escherichia coli co-overexpressing CadA and CadB. Biotechnol Lett 37(4):799-806. doi:10.1007/ s10529-014-1753-5

Makino T, Skretas G, Georgiou G (2011) Strain engineering for improved expression of recombinant proteins in bacteria. Microb Cell Fact 10:32. doi:10.1186/1475-2859-10-32

Marquardt T, von der Heyde A, Elleuche S (2014) Design and establishment of a vector system that enables production of multifusion proteins and easy purification by a two-step affinity chromatography approach. J Microbiol Methods 105:47-50. doi:10.1016/j.mimet.2014.07.008

Neddersen M, Elleuche S (2015) Fast and reliable production, purification and characterization of heat-stable, bifunctional enzyme chimeras. AMB Express 5(1):122. doi:10.1186/s13568-015-0122-7

Rizk M, Antranikian G, Elleuche S (2012) End-to-end gene fusions and their impact on the production of multifunctional biomass degrading 
enzymes. Biochem Biophys Res Commun 428(1):1-5. doi:10.1016/j. bbrc.2012.09.142

Rizk M, Elleuche S, Antranikian G (2015) Generating bifunctional fusion enzymes composed of heat-active endoglucanase (Cel5A) and endoxylanase (Xy|T). Biotechnol Lett 37(1):139-145. doi:10.1007/ s10529-014-1654-7

Rizk M, Antranikian G, Elleuche S (2016) Influence of linker length variations on the biomass-degrading performance of heat-active enzyme chimeras. Mol Biotechnol. doi:10.1007/s12033-016-9925-2

Rosano GL, Ceccarelli EA (2014) Recombinant protein expression in Escherichia coli: advances and challenges. Front Microbiol 5:172. doi:10.3389/ fmicb.2014.00172
Sivashanmugam A, Murray V, Cui C, Zhang Y, Wang J, Li Q (2009) Practical protocols for production of very high yields of recombinant proteins using Escherichia coli. Protein Sci 18(5):936-948. doi:10.1002/pro.102

Tan S (2001) A modular polycistronic expression system for overexpressing protein complexes in Escherichia coli. Protein Expr Purif 21 (1):224-234. doi:10.1006/prep.2000.1363

Tripathi NK, Sathyaseelan K, Jana AM, Rao PVL (2009) High yield production of heterologous proteins with Escherichia coli. Defence Sci J 59:137-146

\section{Submit your manuscript to a SpringerOpen ${ }^{\odot}$ journal and benefit from:}

- Convenient online submission

- Rigorous peer review

- Immediate publication on acceptance

- Open access: articles freely available online

- High visibility within the field

- Retaining the copyright to your article

Submit your next manuscript at $\gg$ springeropen.com 